ROCZNIKI NAUK PRAWNYCH

Tom XXXI, numer $1-2021$

DOI: https://doi.org/10.18290/rnp21311-5

EMIL KRUK

\title{
PROCEDURAL POWERS OF SOCIAL ORGANIZATIONS IN ANIMAL PROTECTION MATTERS*
}

\section{INTRODUCTION}

The issue in question covers the problem of civic control over the process of implementing the norms of substantive law setting out the models of human behaviour towards animals as beings capable of suffering. In this respect, civic control is exercised mainly by social organizations whose statutory objective is to protect animals. This is reflected in the provisions of the Act of 21 August 1997 on the protection of animals ${ }^{1}$ (hereinafter referred to as APA), which grants these organizations a number of various powers. In the literature, they are divided into four main categories: (1) subsidiary powers; (2) sovereign powers; (3) consulting powers; (4) procedural powers ${ }^{2}$. And even if we share

EMIL KRUK PhD - assistant professor at the Department of Administrative Law and Administrative Sciences, Institute of Legal Sciences, Faculty of Law and Administration of the Maria CurieSkłodowska University in Lublin, pl. M. Curie-Skłodowskiej 5, 20-031 Lublin; Poland; e-mail: emil.kruk@umcs.pl; https://orcid.org/0000-0002-7954-0303.

Dr EMIL KRUK - adiunkt, Katedra Prawa Administracyjnego i Nauki o Administracji, Instytut Nauk Prawnych, Wydział Prawa i Administracji Uniwersytetu Marii-Curie Skłodowskiej, pl. M. Curie-Skłodowskiej 5, 20-031 Lublin; e-mail: emil.kruk@umcs.pl; ORCID: https://orcid.org/ 0000-0002-7954-0303.

* The publication was prepared within the research entitled "The Administrative Law Animal Protection Model" included in the application registered in the Funding Stream Service system administered by National Information Processing Institute after number 2016/23/D/HS5/01820 and accepted for financing within the competition announced by the National Science Centre, Poland - "SONATA 12" on the basis of the decision made by the Director of National Science Centre in Krakow of the 16 of May 2017 (decision no. DEC-2016/23/D/HS5/01820, contract no. UMO-2016/ 23/D/HS5/01820).

${ }^{1}$ Journal of Laws of 2020, item 638.

2 Ł. SMAGA, Ochrona humanitarna zwierząt, Białystok: Agencja Wydawniczo-Edytorska EkoPress 2010, p. 270. 
the view that the regulations on these powers are characterised by "randomness and marginality", they determine the possibility (effectiveness) of any action of social organizations in this area. This applies in particular to the participation of a social organization in administrative or judicial proceedings, and this issue will be discussed further herein. The discussion on this issue is all the more necessary as the use of procedural powers by social organizations in animal protection matters raises a number of legal questions. These particularly include divergent opinions concerning: 1) the meaning of the term "social organization" adopted in APA; 2) the conditions for the participation of the social organization in administrative procedure and the nature of that participation; 3) the conditions for the exercise by social organizations of the rights of the aggrieved party in criminal proceedings, in infractions proceedings and in juvenile proceedings. These issues will be further discussed in the order as above. On the other hand, the findings made in this regard will be complemented by comments on the recent amendments to the APA on the procedural powers of social organizations whose statutory objective is to protect animals.

\section{THE CONCEPT OF SOCIAL ORGANIZATION}

The research objective requires that the subjective scope of the term "social organization whose statutory objective is to protect animals" be defined, which is even more necessary since some scholars in the field understand this term in a doubtful way. An example is the opinion presented by Wojciech Radecki, according to whom this term concerns only organizations with statutes, such as association (so-called registered association) within the meaning of the Act of 7 April 1989 Law on Associations ${ }^{4}$. That reasoning leads W. Radecki to the wrong conclusion that the term in question does not cover a simplified form of association, namely unincorporated (ordinary) association, which has no statutes and defines its objectives in its internal rules. According to that author, "if a social organization wishes to be taken seriously, it should lay down its statutes, register and acquire legal personality" (sic!). In view of the above, W. Radecki considers ordinary associations to be devoid of procedural powers ${ }^{5}$. However, it should be borne in mind that, in accordance with

\footnotetext{
${ }^{3}$ Ibidem.

${ }^{4}$ Journal of Laws of 2020, item 2261.

${ }^{5}$ W. RADECKI, Ustawy o ochronie zwierzat. Komentarz, Warszawa: Difin SA 2015, p. 259.
} 
Article 43(2) of the Law on Associations, the internal rules of the ordinary association have the legal significance of statutes of the incorporated association $^{6}$. One should agree with Robert Kędziora, who argues that: "The concept of the statutory objective of a social organization must be understood broadly as the objective of the social activity of a social entity, even if the entity does not have statutes in the sense in which that term is sometimes used for an act regulating the structure and activities of a legal person" "7. And some even assume that the objectives of a particular social organization expressed in the very name of the organization have the attribute of "statutory objectives" 8 in the meaning of Article $31 \S 1$ of the Code of Administrative Procedure ${ }^{9}$ [hereinafter: CAP].

At this point, it is also worth noting that the definition of "social organization" in general administrative procedure is contained in Article $5 \S 2$ point 5 CAP, according to which it should be understood as professional organizations, local government organizations, cooperative organizations and other social organizations. Unfortunately, due to the high degree of generality, this term raises numerous practical doubts regarding the admissibility to consider as social organizations also foundations, commercial companies, local government units, auxiliary units of local government or political parties ${ }^{10}$. As pointed out in the administrative courts case law, article 12 of the Polish Constitution, which expresses the principle of citizens' participation in the functioning of the state by establishing various types of organizations and structures allowing citizens to pursue their interests and express their opinions. In line with this principle, citizens enjoy the freedom to create organizations and structures in the form they choose. According to the literal wording of article 12 of the Constitution of the Republic of Poland, "The Republic of Poland shall ensure freedom for the creation and functioning of trade unions, sociooccupational organizations of farmers, societies, citizens' movements, other

\footnotetext{
${ }^{6}$ See B. Adamiak, Komentarz do art. 31, [in:] B. AdamiaK, J. Borkowski, Kodeks postepowania administracyjnego. Komentarz, Legalis 2019/el.

${ }^{7}$ See R. KęDziora, Kodeks postępowania administracyjnego. Komentarz, Legalis 2017/el., komentarz do art. 31.

${ }^{8}$ J. Zimmermann, Glosa do postanowienia Naczelnego Sadu Administracyjnego z dnia 15 września 2000 r., I SA 943/00, “Orzecznictwo Sądów Polskich” 2001, no. 7-8, item 109, LEX.

${ }^{9}$ Act of 14 June 1960 Code of Administrative Procedure [Ustawa z dnia 14 czerwca 1960 r. Kodeks postępowania administracyjnego], Journal of Laws of 2020, item 256, as amended.

${ }^{10}$ See e.g. Judgment of the Regional Administrative Court of Bydgoszcz of 23 July 2008, case ref. no. II SA/Bd 917/07, CBOSA.
} 
voluntary associations and foundations." Thus, the constitution-makers allowed the possibility to exercise the right of association in various organisational forms. On the other hand, the specification of the organizations listed in article 12 of the Constitution of the Republic of Poland allows for identifying their common features, which may be regarded as constitutive features of social organizations. These are: 1) voluntary membership, understood as the freedom to associate without State's interference; 2) the legally defined structure and scope of rights and obligations, which determines the organisational separateness and independence of social organizations; 3 ) the objectives of social organizations and their activities must be consistent with objectives of the State; 4) the governing bodies of social organizations are created by way of election by members of these organizations; 5) social organizations remain under the control or supervision of public authorities. Bearing all this in mind, the Supreme Administrative Court rejects as a constitutive feature of social organization its corporate character i.e. that the essence of social organization is the association of citizens in the form of membership. According to the Supreme Administrative Court, a social organization is an organization or structure established by citizens in order to pursue their plans, and the constitutionally guaranteed "freedom to establish an organization is also the freedom to choose the legal form of exercising this freedom"11.

Leaving aside the very concept of social organization, it should be stressed that the legislature provided for in the APA the special powers (including procedural ones) only for those social organizations whose statutory objective is to protect animals. The objective of activity of a given organization should be specified precisely enough to provide a basis for a conclusion about its actual and direct connection with the matter of a given proceeding (whether administrative or judicial). Hence, for example, a social organization whose statutory objective is environmental protection in the broad sense, when applying for participation in an animal protection proceeding, must demonstrate how the matter of the proceeding is related to its statutory activity. It must point to specific factual and legal circumstances that may indicate that the organization will actively contribute to a better fulfilment of the objectives of the pending proceeding. In other words, the basic precondition of the procedural initiative of a social organization is the compliance of its objective with the matter of the proceeding. The legislature does not prioritize these objectives in any way, and does not require that it be a direct objective, let alone exclusive one.

\footnotetext{
${ }^{11}$ Resolution of the Supreme Administrative Court of 12 December 2005, II OPS 4/05, CBOSA.
} 
It does not require demonstrating the relationship between the matter of the case and the achievements and specialization of activities of members. The complexity of the proceeding, as well as the specialist knowledge required to carry it out, are irrelevant here. The law does not provide for such conditions.

\section{PARTICIPATION IN ADMINISTRATIVE PROCEEDINGS}

As far as the general administrative procedure is concerned, a social organization may participate either as a party or an entity exercising rights of a party, depending on the situation. In the latter case, the basis for action is the provision of procedural law, and more specifically article $31 \mathrm{CAP}$, pursuant to which a social organization in a case concerning another person may submit the following requests: 1) to initiate the proceedings, 2) to be allowed to participate in the proceedings if it is justified by the organization's statutory objectives and where it is justified by the public interest. The public administration body considering the request of the social organization decides to initiate proceedings ex officio or to allow the organization to participate in the proceedings. In such a situation, the social organization participates in proceedings concerning a third party's legal interest or obligation. Consequently, such an organization may not carry out the legally effective activities which are an expression of the principle of disposition in administrative proceedings. In other words, it may neither decide about the very proceeding nor do so as regards the rights or obligations covered by the proceeding. Naturally, a social organization will also not be the addressee of a decision concluding an administrative case covered by administrative jurisdictional proceedings in which the organization participates with the rights of a party. Nonetheless, a social organization may demand that the proceedings be initiated or the organization be allowed to the proceeding to support a party, or to oppose party's demands and interests, or the organization may act on behalf of one of the parties for strengthening its position in the proceedings, and its procedural activities may be unrelated to the interests of any of the parties, but undertaken for the public interest. It should also be kept in mind that the burden of proving the existence of the prerequisites for granting the organization the status of an entity with rights of a party is borne by the organization. It is not enough for a social organization to generally state that it acts in the public interest or that it takes action to protect animals. It is necessary to list specific factual and legal circumstances which may indicate that the organization should take part in the 
proceedings. Nonetheless, it the responsibility of the public administration body to assess whether the organization meets the conditions for granting the status of an entity with rights of a party. However, the administrative body is not obliged to accept the request of the social organization. Even if the participation of the social organization is justified by its statutory objectives, the administrative body must examine whether this participation is also in the public interest. As the literature points out: "The participation of a social organization in proceedings under the commented regulations cannot serve own interests of the social organization itself, but must meet the requirements of a rationally understood social control over administrative proceedings in individual cases and the operation of public administration bodies as part of them" 12 .

The aforementioned article 31 CAP does not apply where the administrative proceeding concerns a legal interest or obligation of a social organization. Pursuant to article $28 \mathrm{CAP}$, the social organization will be in such a case a party to the proceedings ${ }^{13}$, and as a result of deciding the case it will become an entity with rights or obligations specified in an administrative act. Applying these considerations to the area of the APA, it is worth pointing to its article 7(3), the application of which has resulted in discrepancies in the administrative courts case law. It is, first of all, about the doubt whether, in proceedings aimed at issuing a decision under article 7(3) APA in fine, a social organization whose statutory objective is to protect animals, and whose authorised representative, acting under this provision, took an animal away from its owner or guardian and notified the mayor of this fact - has the status of a party within the meaning of article 28 CAP: When referring to this issue, the Supreme Administrative Court stated as follows in the explanatory resolution of 24 February 2020: "There is no doubt that the proceedings conducted under article 7 (3) in conjunction with article 7 (1) of the Act on the Protection of Animals concern the legal obligation of the entity which took away the animal. It is about sanctioning by an administrative decision that the entity which took away the animal has fulfilled its obligation and has not exceeded its powers and has not illegally interfered with someone else's property. The position of the party can also be based on the fact that defence against an allegation of

\footnotetext{
${ }^{12}$ See B. AdAmiaK, Komentarz do art. 31.

${ }^{13}$ See E. KUDASIK-GIL, Status strony $i$ wszczęcie postępowania na gruncie art. 7 ust. 3 ustawy o ochronie zwierzat - wybrane problemy interpretacyjne, "Przegląd Prawa Administracyjnego" 2 (2019), pp. 69-80; P. OsTOJSKI, Organizacja spoleczna jako strona postępowania w sprawie odebrania zwierzęcia na podstawie art. 7 ust. 3 ustawy o ochronie zwierząt, "Przegląd Prawa i Administracji” 116 (2019), pp. 73-85.
} 
unlawful interference in someone else's property resulting from the refusal to issue the decision is in the legal interest of the person who took away the animal"14. This is extremely important since the participation of a social organization as a party to proceedings under article 7(3) APA guarantees its equal position vis-à-vis the owner or guardian of the animal taken away. The position of a party to the proceedings gives the person who took away the animal the opportunity to lodge an appeal and then bring an action to the regional administrative court. The only question is: is the SAC's interpretation correct?

This issue is perceived differently by e.g. Ewa Szewczyk and Marek Szewczyk. They argue that the Supreme Administrative Court wrongly decoded the normative meaning of the phrase "takes the animal away from him" used in article 7(3) APA, which determined the further course of its reasoning and ultimately led to the conclusion that the social organization could be a party to the administrative procedure regarding the taking away of the animal. According to the commentators, the phrase "takes the animal away from him" should not be understood as an authorisation to take a factual act, as assumed by the SAC, but as an authorisation to issue a so-called informal administrative act. On the other hand, the essential content of that act is a request to give out the animal, formulated under a statutory authorisation, addressed to its owner or guardian. In support of their thesis, E. Szewczyk and M. Szewczyk point out that informal administrative acts are law application acts (administrative-law acts), while "the application of law is not the domain of the administered entities which may enjoy the right of a party in the context of judicial administrative proceedings. The application of law is only the responsibility of administering entities" $"$. With this in mind, the authors claim that a representative of a social organization, acting on the basis of article 7(3) APA, carries out a sovereign act (of a police character), and therefore acts as an administrative entity in the case in question. However, a view is established both in the administrative case-law and scholarly opinion that an entity cannot act in two roles in the same case: as the body conducting the proceedings (the administering entity) and as a party (the administered entity). As a rule, these roles cannot be combined. Nor is it permissible for the same entity to first

\footnotetext{
${ }^{14}$ Resolution of the Supreme Administrative Court of 24 February 2020, II OPS 2/19, CBOSA.

${ }^{15}$ E. SZEWCZYK, M. SZEWCZYK, Status organizacji społecznej w postepowaniu prowadzacym do wydania decyzji na podstawie art. 7 ust. 3 in fine ustawy z dnia 21 sierpnia 1997 r. o ochronie zwierzat. Glosa do uchwaty Naczelnego Sądu Administracyjnego z dnia 24 lutego 2020 r., II OPS 2/19, “Orzecznictwo Sądów Polskich" 2020, no 9, p. 143.
} 
occupy the position of an administrative body and then the position of a party, depending on the stage of processing a public administration case. In addition, the case-law of the administrative courts has developed a rule of giving priority to the role of the administering entity (case processing entity) ${ }^{16}$. E. Szewczyk and M. Szewczyk also take the view that the provision of article 7(3) APA does not confer any substantive-law right on a social organization - it is not a source of its legal interest $\mathrm{t}^{17}$. In their opinion: "The norm expressed in Article 7(3) APA grants a social organization the sovereign power to demand a particular conduct from an administered entity, specifically in this case an animal owner or guardian" ${ }^{18}$. The view expressed by these authors must be regarded as right and fully justified.

\section{PARTICIPATION IN CRIMINAL PROCEEDINGS}

Procedural powers of social organizations includes also participation in criminal proceedings. For example, in accordance with article 39 APA, in cases of crimes referred to in article 35(1), (1a) or (2) APA and for the crimes referred to in article 37 APA as well as in juvenile proceedings for the crime referred to in article 35(1), (1a) or (2) of the Act, the rights of the aggrieved party may be exercised by a social organization whose statutory objective covers the protection of animals. It is worth emphasising that under the legislation currently in force, the right in question is not conditional on the inactivity of the aggrieved party, who in the procedural sense can only be the owner or holder of the animal. This does not concern a situation where the crime under article 35 (1), (1a) or (2) APA or infraction under 37 APA is committed by the owner of the animal, which is quite frequent in practice ${ }^{19}$. In this case there is simply no aggrieved party in the procedural sense. It is unacceptable to

\footnotetext{
${ }^{16}$ Judgment of the Supreme Administrative Court of 9 October 2013, case ref. no. II OSK 1082/12, CBOSA.

${ }^{17}$ Similarly: M. RAGUSZEWSKA, Udziat w postepowaniu organizacji społecznej, której statutowym celem działania jest ochrona zwierzą - decyzja Samorządowego Kolegium Odwoławczego we Wrocławiu z 10 kwietnia 2019 r. (SKO 5141/2/19), "Orzecznictwo w Sprawach Samorządowych" 2019, no. 2, p. 36.

${ }^{18}$ E. SZEWCZYK, M. SZEWCZYK, Status organizacji spolecznej, p. 145.

${ }^{19}$ This problem is also pointed to in the non-Polish literature, see e.g. K. TAPERSON, Loomade poolt, Hiiumaa: MTÜ Loomus 2016, https://loomus.ee/wp-content/uploads/2016/12/Loomade_ Poolt.pdf [accessed: 26.12.2020], p. 25.
} 
assume otherwise, as it would lead to the absurd conclusion that the perpetrator is also the victim ${ }^{20}$. Thus, the regulation of Article 39 APA gives social organizations the possibility to exercise the rights of an aggrieved party, both when there is no aggrieved party in the procedural sense, and when the aggrieved party exists, but does not act in criminal proceedings or in proceedings on infractions. It should be noted that participation in the trial of an entity exercising the rights of an aggrieved party is not necessary. The above-mentioned crimes and infractions are prosecuted by public indictment ex officio.

A detailed analysis of the social organization rights related to the exercise of the rights of the aggrieved party in criminal proceedings, infractions proceedings or in juvenile proceedings goes beyond the framework of this study ${ }^{21}$. It is, however, necessary to point to the most important procedural institutions that may be used by social organizations in the course of these proceedings. Beginning with criminal proceedings ${ }^{22}$, the following should be mentioned first and foremost: the possibility to report a crime and lodge a complaint against a possible refusal to initiate proceedings (article $306 \S 1$ of the Code of Criminal Procedure); the possibility of participating as a party in pre-trial proceedings (article $299 \S 1$ of the Code of Criminal Procedure); the possibility of lodging a complaint against a decision to discontinue pre-trial proceedings (article $306 \S 1 \mathrm{a}$ of the Code of Criminal Procedure); the possibility to appear at the hearing as an auxiliary prosecutor along the public prosecutor (article 54 of the Code of Criminal Procedure); possibility to bring one's own indictment if the prosecutor twice refused to initiate the proceedings or discontinued the proceedings (article 55 of the Code of Criminal Procedure); possibility to actively participate in the hearing and to appeal against the judgment of the court of first instance.

\footnotetext{
${ }^{20}$ See A. ChOROMAŃSKA, Status pokrzywdzonego w sprawach o przestępstwo znęcania się nad zwierzętami. Uwagi na tle wyroku Sadu Najwyższego z 16 stycznia 2014 r. (VKK 370/13), [in:] Przeciwdziałanie międzynarodowej przestępczości przeciwko środowisku naturalnemu z perspektywy organów ścigania, eds. W. Pływaczewski, A. Nowak, M. Porwisz, Szczytno: Wydawnictwo Wyższej Szkoły Policji w Szczytnie 2017, p. 202.

${ }^{21}$ See A. ZIENTARA, Udziat organizacji spolecznych w postępowaniach o wykroczenia z ustawy o ochronie zwierząt, [in:] Sprawiedliwość dla zwierząt, eds. B. Błońska, W. Gogłoza, W. Klaus, D. Woźniakowska-Fajst, Warszawa: Instytut Nauk Prawnych Polskiej Akademii Nauk, Stowarzyszenie "Otwarte Klatki” 2017, pp. 166-178; M. PoRwISZ, Udziat w postępowaniu karnym organizacji społecznych działających na rzecz ochrony zwierząt, [in:] Przeciwdziałanie międzynarodowej przestępczości, pp. 207-224.

${ }^{22}$ See Act of 6 June 1997 Code of Criminal Procedure [Ustawa z dnia 6 czerwca 1997 r. Kodeks postępowania karnego], Journal of Laws of 2020, item 30, as amended [hereinafter: CCP].
} 
The exercise of the rights of the aggrieved party by a social organization in infractions proceedings is more complex. The code of procedure in cases of infractions ${ }^{23}$ does not treat the aggrieved as a party to the proceedings only because he/she is the aggrieved. The active participation in infractions proceedings depends on having the status of an auxiliary prosecutor. This results from article $25 \S 4$ of the Code of Procedure in Infractions, according to which the aggrieved party may act as a party in the capacity of auxiliary prosecutor alongside or instead of the public prosecutor. This regulation should also apply to entities that have been granted the rights of the aggrieved party, including social organizations whose statutory objective is the protection of animals (article 39 APA). It should also be noted that the legislature granted such rights to social organizations solely in cases of infractions specified in article 37 APA. Such rights are not vested in social organizations in cases of infractions described in articles 37 a to 37 e APA.

This issue is presented differently under the Act of 26 October 1982 on proceeding in juvenile matters ${ }^{24}$. Pursuant to the provisions of this Act, a minor (i.e. a person under 18 years of age) does not commit a crime, but a punishable prohibited act. According to article 39 APA, if such an act is an act as defined in article 35 (1), (1a) or (2) APA, a social organization whose statutory activity is the protection of animals may exercise the rights of the aggrieved party in proceedings before a court hearing cases against minors ${ }^{25}$.

It is worth noting that the power to exercise the rights of the aggrieved party is vested in social organizations only in cases of crimes, infractions and punishable acts indicated by the legislature in the APA and in the Act on the protection of animals used for scientific or educational purposes. In any case, it does not cover all such acts, which significantly limits the procedural powers of social organizations. Therefore, there is a need to strengthen their role, which was also noticed at some point by the legislature. This is manifested by the proposal, submitted in 2015 as part of the MP's bill amending the Act on the protection of animals and certain other acts (Sejm paper no. 3744), reading as follows: "Social organizations whose statutory objective is to protect animals, may initiate proceedings or participate as parties in pending criminal, civil, administrative or judicial administrative proceedings, if there is a need

\footnotetext{
${ }^{23}$ Act of 24 August 2001 Code of Procedure in Infractions [Ustawa z dnia 24 sierpnia $2001 \mathrm{r}$. - Kodeks postępowania w sprawach o wykroczenia], Journal of Laws of 2020, item 729, as amended [hereinafter: $\mathrm{CPI}$.

${ }^{24}$ Journal of Laws of 2018, item 969.

${ }^{25}$ W. RADECKI, Ustawy o ochronie zwierząt, pp. 261-263.
} 
to protect animals" ${ }^{\prime 2}$. Regretfully, work on this bill stopped at the stage of the first reading in parliamentary committees.

\section{PLANNED DIRECTIONS OF CHANGE}

Continuing the topic addressed above, it is worth mentioning the recent proposal to change the procedural powers of social organizations whose statutory objective is to protect animals. These include the solutions provided for under the bill processed currently in the Sejm amending the Animal Protection Act and certain other acts (Sejm paper No 597) ${ }^{27}$. Thus, in accordance with the provisions of that Act, the Minister responsible for public administration would keep a list of non-governmental organizations entitled to: 1) request the initiation of an administrative procedure or request being allowed to participate in an ongoing administrative procedure in an animal protection case; 2) bring a civil action to protect animals; 3 ) exercise rights of the aggrieved party in cases of crimes involving an animal or the environment. However, only an NGO that meets the following conditions cumulatively could apply for an entry on such a list: 1) having at least two years' experience in carrying out animal rights tasks; 2) having the status of a public benefit organization within the meaning of article 20 of the Act of 24 April 2003 on public benefit activities and voluntary service ${ }^{28} ; 3$ ) having a cooperation agreement on the protection of animal rights concluded with an advocate or attorney-at-law; 4) providing a guarantee of the proper exercise of rights aimed at animal protection. Administrative decisions regarding the registration on the list, refusal of registration and deletion of an NGO from the list would be issued by the Minister responsible for public administration. It is worth noting that the organization would only be registered at the request of the NGO concerned. On the other hand, an NGO would be deleted from the list where that organization:

\footnotetext{
${ }^{26}$ Poselski projekt ustawy o zmianie ustawy o ochronie zwierząt oraz niektórych innych ustaw (druk nr 3744), http://www.sejm.gov.pl/sejm7.nsf/druk.xsp?nr=3744 [accessed: 26.12.2020].

${ }^{27}$ Ustawa o zmianie ustawy o ochronie zwierząt oraz niektórych innych ustaw (druk nr 597) uchwalona na 17 posiedzeniu Sejmu RP w dniu 18 września 2020 r., https://www.sejm.gov.pl/Sejm9. nsf/PrzebiegProc.xsp?nr=597 [accessed: 26.12.2020]. On 14 October 2020, the Polish Senate adopted a resolution (Sejm paper no. 677) whereby it proposed a number of modifications to this Act. On 15 October 2020, the bill was submitted to the Sejm's Committee of Agriculture and Rural Development. The work on it are still under way.

${ }^{28}$ Journal of Laws of 2020, item 1057.
} 
1) has ceased its animal rights activities as a result of amendments to the organization's statutes or other internal act defining the scope of its activities; 2) no longer meets any of the above-mentioned conditions. This list would be made available in the Public Information Bulletin (Biuletyn Informacji Publicznej).

In view of the above-mentioned assumptions, the amendment in question also contains the relevant procedural provisions intended to supplement the APA, but also the Code of Civil Procedure and the Code of Criminal Procedure. Those provisions expressly give non-governmental organizations included in the list the right to initiate administrative proceedings in animal protection cases, to participate in it with the rights of a party and to challenge before an administrative court a decision taken in the course of such administrative proceedings. As regards the right to bring an action before administrative court, it would also be available to those organizations if they did not take part in the administrative procedure concerned. On the other hand, the Code of Civil Procedure would be supplemented by a provision authorising nongovernmental organizations to bring an action "for the protection of animals". As regards the Code of Criminal Procedure, it would contain a regulation according to which, in cases of animal-related crimes and in cases of crimes referred to in Chapter XXII of the Criminal Code ${ }^{29}$, the non-governmental organizations on the list could exercise the rights of the aggrieved party if they have revealed a crime or have requested the initiation of proceedings.

Since parliamentary work on the Act in question was abandoned and the current government coalition intends to prepare a new draft amendment to the APA, it would be unreasonable to analyse in detail the solutions presented above $^{30}$. The very direction of the proposed changes, namely the strengthening of the procedural powers of social organizations whose statutory objective is to protect animals should be assessed as correct. This is even more obvious if we take into account the fact that organizations of this type are currently the only guarantor of effective implementation of the idea of humane animal protection in Poland.

\footnotetext{
${ }^{29}$ Act of 6 June 1997, Penal Code [Ustawa z dnia 6 czerwca 1997 r. - Kodeks karny], Journal of Laws of 2020, item 1444, as amended.

${ }^{30}$ M. KolanKo, Widmo nowej ,piatki dla zwierzat”. Projekt to kwestia czasu, "Rzeczpospolita" of 30 November 2020, https://www.rp.pl/Polityka/311309904-Widmo-nowej-piatki-dla-zwierzatProjekt-to-kwestia-czasu.html [accessed: 26.12.2020]; M. RUDY, O. SUSZEK, Nowelizacja ustawy o ochronie zwierzat. Co ostatecznie uchwalit Sejm?, https://www.swps.pl/strefa-prawa/artykuly/ 22484-nowelizacja-ustawy-o-ochronie-zwierzat-co-ostatecznie-uchwalil-sejm?fbclid=IwAR2E4a XDWvA8g8WKIT95gQQYkn98sIfSy3d_j-7WdZzHhGFo8kUrYt4dsCA [accessed: 26.12.2020].
} 


\section{CONCLUSION}

Social activity and cooperation between society and government institutions are essential elements that increase the internal security of the State at all levels. That is why it is so important that the regulations addressed to social organizations whose statutory objective is to protect animals should have an appropriate normative value, which is expressed in the scale of their practical application. It is not a matter of replacing state bodies and shifting the burden of responsibility for the situation of animals to social organizations, but a clearly defined position of the social element by equipping social organizations with powers that enable them to take effective action and have a real effect on animal protection. Unfortunately, most of the provisions of the APA, which define the various roles of social organizations in this area, can be considered too vague and anachronistic. In a way, this also applies to the regulations on procedural powers of social organizations. The best example of this is the aforementioned power to exercise the rights of the aggrieved party, which does not cover all negatively qualified acts, but only those indicated by the legislature in APA and in the Act on the protection of animals used for scientific or educational purposes. Such solutions are not justified whatsoever and significantly limit the possibilities and effectiveness of social organizations, which in turn leads to the formulation of a postulate about the need to strengthen their role.

\section{REFERENCES}

ADAMIAK Barbara, BORKOWSKI Janusz: Kodeks postępowania administracyjnego. Komentarz, Legalis 2019/el.

ChoromańsKa Agnieszka: Status pokrzywdzonego w sprawach o przestępstwo znęcania się nad zwierzętami. Uwagi na tle wyroku Sądu Najwyższego z 16 stycznia 2014 r. (VKK 370/13), [in:] Przeciwdziałanie międzynarodowej przestępczości przeciwko środowisku naturalnemu z perspektywy organów ścigania, eds. W. Pływaczewski, A. Nowak, M. Porwisz, Szczytno: Wydawnictwo Wyższej Szkoły Policji w Szczytnie 2017, pp. 197-206.

KĘDZIORA Robert: Kodeks postępowania administracyjnego. Komentarz, Legalis 2017/el.

KolanKo Michał: Widmo nowej ,piątki dla zwierząt”. Projekt to kwestia czasu, "Rzeczpospolita” z dnia 30 listopada 2020, https://www.rp.pl/Polityka/311309904-Widmo-nowej-piatki-dlazwierzat-Projekt-to-kwestia-czasu.html [accessed: 26.12.2020].

KUDASIK-GIL Emilia: Status strony i wszczęcie postępowania na gruncie art. 7 ust. 3 ustawy o ochronie zwierząt - wybrane problemy interpretacyjne, "Przegląd Prawa Administracyjnego" 2 (2019), pp. 69-80.

OsTOJSKI Przemysław: Organizacja społeczna jako strona postępowania w sprawie odebrania zwierzęcia na podstawie art. 7 ust. 3 ustawy o ochronie zwierząt, "Przegląd Prawa i Administracji" 116 (2019), pp. 73-85. 
PORWISZ Monika: Udział w postępowaniu karnym organizacji społecznych działających na rzecz ochrony zwierząt, [in:] Przeciwdziałanie międzynarodowej przestępczości przeciwko środowisku naturalnemu z perspektywy organów ścigania, eds. W. Pływaczewski, A. Nowak, M. Porwisz, Szczytno: Wydawnictwo Wyższej Szkoły Policji w Szczytnie 2017, pp. 207-224.

RADECKI Wojciech: Ustawy o ochronie zwierząt. Komentarz, Warszawa: Difin SA 2015.

RAGUSZEWSKA Magdalena: Udział w postępowaniu organizacji społecznej, której statutowym celem działania jest ochrona zwierząt - decyzja Samorządowego Kolegium Odwoławczego we Wrocławiu z 10 kwietnia 2019 r. (SKO 5141/2/19), "Orzecznictwo w Sprawach Samorządowych" 2019, no. 2, pp. 34-37.

RuDY Michał, SuszeK Olga: Nowelizacja ustawy o ochronie zwierząt. Co ostatecznie uchwalił Sejm?, https://www.swps.pl/strefa-prawa/artykuly/22484-nowelizacja-ustawy-o-ochronie-zwierzat-co-osta tecznie-uchwalil-sejm?fbclid=IwAR2E4aXDWvA8g8WKIT95gQQYkn98sIfSy3d j-7WdZzHhG Fo8kUrYt4dsCA [accessed: 26.12.2020].

SMAGA Łukasz: Ochrona humanitarna zwierząt, Białystok: Agencja Wydawniczo-Edytorska EkoPress 2010.

SZEWCZYK Ewa, SZEWCZYK Marek: Status organizacji społecznej w postępowaniu prowadzącym do wydania decyzji na podstawie art. 7 ust. 3 in fine ustawy z dnia 21 sierpnia 1997 r. o ochronie zwierząt. Glosa do uchwały Naczelnego Sądu Administracyjnego z dnia 24 lutego 2020 r., II OPS 2/19, “Orzecznictwo Sądów Polskich” 2020, no. 9, pp. 127-147.

TAPERSON Kadri: Loomade poolt, Hiiumaa: MTÜ Loomus 2016, https://loomus.ee/wp-content/ uploads/2016/12/Loomade_Poolt.pdf [accessed: 26.12.2020].

ZIENTARA Anna: Udział organizacji społecznych w postępowaniach o wykroczenia $\mathrm{z}$ ustawy o ochronie zwierząt, [in:] Sprawiedliwość dla zwierząt, eds. B. Błońska, W. Gogłoza, W. Klaus, D. Woźniakowska-Fajst, Warszawa: Instytut Nauk Prawnych Polskiej Akademii Nauk, Stowarzyszenie "Otwarte Klatki" 2017, pp. 166-178.

ZiMMERMANN Jan: Glosa do postanowienia Naczelnego Sądu Administracyjnego z dnia 15 września 2000 r., I SA 943/00, “Orzecznictwo Sądów Polskich” 2001, no. 7-8, poz. 109, LEX.

\section{PROCEDURAL POWERS OF SOCIAL ORGANIZATIONS IN ANIMAL PROTECTION MATTERS}

\section{S u m m a ry}

The main aim of the article is to discuss the procedural powers of social organizations whose statutory objective is to protect animals. The research was aimed primarily at determining the prerequisites for the possibility of participation of a social organization in administrative proceedings and the prerequisites for social organizations to exercise the rights of the aggrieved party in criminal proceedings, in infractions proceedings and in juvenile proceedings. The findings made in this regard are complemented by comments on the recent amendments to the Act of 21 August 1997 on the protection of animals, regarding the procedural powers of social organizations whose statutory objective is to protect animals.

Keywords: law; animal protection; humanitarian protection; non-governmental organizations; social control 


\section{KOMPETENCJE PROCESOWE ORGANIZACJI SPOŁECZNYCH W SPRAWACH DOTYCZĄCYCH OCHRONY ZWIERZĄT}

\section{Streszczenie}

W artykule autor omawia kompetencje procesowe organizacji społecznych, których statutowym celem działania jest ochrona zwierząt. Przeprowadzone badanie ukierunkowane było przede wszystkim na określenie przesłanek warunkujących możliwość uczestnictwa organizacji społecznej w postępowaniu administracyjnym oraz przesłanek warunkujących możliwość wykonywania przez organizacje społeczne praw pokrzywdzonego w postępowaniu karnym, w postępowaniu w sprawach o wykroczenia oraz w postępowaniu w sprawach nieletnich. Uzupełnieniem poczynionych w tym zakresie ustaleń są uwagi dotyczące postulowanych w ostatnim czasie zmian w ustawie z dnia 21 sierpnia 1997 r. o ochronie zwierząt, odnoszące się do kompetencji procesowych organizacji społecznych, których statutowym celem działania jest ochrona zwierząt.

Słowa kluczowe: prawo; ochrona zwierząt; ochrona humanitarna; organizacje pozarządowe; kontrola społeczna 